\title{
ISSUES OF FINANCING LITHUANIAN HIGHER EDUCATION INSTITUTIONS
}

\author{
Saulius Greičius \\ Birutė Pranevičienė \\ Aurelija Pūraitè \\ Agnè Margevičiūtė \\ Mykolas Romeris University, Faculty of Public Security, Lithuania
}

\begin{abstract}
Higher education of Lithuania and its legal regulations constantly undergo various changes - both necessary and timely, as well as quite chaotic and fragmented. There have recently been a number of reforms implemented in the field of higher education in Lithuania, related to the financing of higher education, management, transformations of the influence of the state institutions on higher education institutions. The new reform of the whole system of higher education is being planned to begin in 2017, it is announced that there will be a drastic decrease in the number of public institutions of higher education and this should lead to improvement of the quality of studies and to better allocation of state finances. The object of the research is features and problems of the financing of higher education in Lithuania. The aim of the research is to present the system of higher education in Lithuania, to evaluate trends in financing of higher education and to determine shortages of legal regulation of this field, disclose problems related to dysfunctions of legal regulations and shortcomings of practical applications. After analysing the main provisions of the financing reform of higher education in Lithuania and evaluating the first results of the reform, conclusions regarding the main shortages and advantages of the reform are provided, other financing alternatives for higher education are suggested.
\end{abstract}

Keywords: financing of higher education, higher education institutions, state regulation, financing methods.

\section{Introduction}

One of the topical aspects of the change in the higher education system in the end of the twentieth century - at the beginning of the twenty - first century in Lithuania as well as in all European Union is the trend towards the massiveness of higher education. On the one hand, this phenomenon should be evaluated as a positive one, indicating that the need for the knowledge and education is increasing. On the other hand, this trend causes many changes in the system of higher education and activities of institutions. Massive higher education also 
requires widely applying non-traditional forms of education to install new systems of management of institutions, to commercialize studies. In addition to the abovementioned challenges, higher education in Lithuania also encounters other predictable difficulties, related to the difficult economic, social and demographic situation in Lithuania. The main financing source of higher education in Lithuania currently is the state, and this trend is prevailing in all EU countries - direct budget assignations in the EU countries for tertiary institutions comprise from 60 percent to 90 percent of their received resource income. State financing methods and mechanisms in different countries are various; their application depends on the goals set by way of state regulation, the economic capacity of the state, the ratio of state institutions. Since the state still remains the main funder of the system of higher education, the applied method of state financing must guarantee effectiveness, quality and must be sufficient. Scholars(Albrecht, Ziderman, 1992;Braun, 1998; Claes-Kulik \& Estermannn, 2015; Conraths, Smidt, 2005; Glosiené, 2005; Edirisooriya, 2003, p. 121-133; EUA Report, 2008; Pruvot, Claes-Kulik, Estermann, 2015; West, 1995) describe several methods of state financing according to its target - institutional financing "in common amount" (also described as "financing by a formula"), programme financing and financing of the service receiver. Bearing in mind the limited financial resources of the state, it is clear that such a financial model leads to various difficulties connected with effectiveness and clarity of financing studies and research.

Higher education of Lithuania and its legal regulation constantly undergoes various changes - both necessary and timely, as well as quite chaotic and fragmented. It is also important to note that the legal regulation of higher education is harmonized and correlates with other means of state regulation financing, quality (licensing, accreditation, and external evaluation), formation and development of political activity strategy. There have recently been a number of reforms implemented in the field of higher education in Lithuania, related to the financing of higher education, management, transformations of the influence of the state institutions on higher education management. Further on, constant discussions regarding financing, quality assurance, accountability to the society, management problems in higher education rise. The new reform of the whole system of higher education is being planned to begin in 2017, it is announced that there will be a drastic decrease in the number of public institutions of higher education and this should lead to improvement of the quality of studies and to better allocation of state finances. Therefore scientific research of these processes is very relevant, important and timely.

The object of the research is trends and problems of the financing of higher education in Lithuania. The aim of this paper is to systematically research the problematic issues of financing higher education in Lithuania, to determine dysfunctions of legal regulation and propose possible alternative models 
financing. Following tasks were raised while seeking the described aim: to present the system of higher education in Lithuania, to evaluate trends of financing of higher education in Lithuania and to determine shortages of legal regulation of this field, to discuss the state funding methods of higher education and to indicate their characteristics, to disclose problems related to dysfunctions of legal regulations and shortcomings of practical applications.

Based on the works of D. Albrecht and A. Ziderman, D. Braun, B. Johnstone and A. Arora, A. Wagner, P. Cazenave, B. Salter and T. Tapper, S. Kmit, L. Kraujutaitytė, J. Salmi and A. M. Hauptman, M. Woodhall, M. Canning, M. Godfrey, D. Holzer-Zelazewska, G. Edirisooriya and other scientists different financing models of higher education, their variety, essential characteristics and influence towards the system of higher education were analysed and conclussions made as a basis for theoretical background for this paper. Significant, in this aspect, are researches carried out by international organizations - the World Bank, European Association of Universities and their reports.

The problem of financing higher education in Lithuania is analysed based on these methods: document analysis (written and statistical data, reports of international organization regarding reforms, strategic development of higher education has been analysed), description (the trends of financing higher education, documents of the EU were described), analytical - critical (the issues of state regulation in the field of higher education in Lithuania were analysed using this method, possible dysfunctions of legal regulation were detected, propositions of legal regulation and alternative financing methods were presented), analyses of scientific literature (using this method the mechanisms of different financing models in the field of higher education were determined and analysed), systematic analysis (the state financing methods and their impact on the whole system of higher education in Lithuania were evaluated using this method of analysis), comparative (this method enabled to present status quo of legal regulation in Lithuania and to compare it with traditions of legal regulation in other countries, which allowed to inspect more precisely the dysfunction of legal regulation), source content analysis (using this method scientific works of Lithuanian and foreign authors were analysed).

\section{The system of higher education of Lithuania and its financing}

Education in institutions of higher education is carried out according to study programmes that grant a degree and those that do not. There are two types of study programmes: college and university level. There is an active national System of ensuring quality of higher education, only accredited study programmes are taught that are registered for a determined period of time in the Registrar of Studies, Study Programmes and Qualifications. There are two types of institutions of 
Saulius Greičius, Birutè Pranevičienè, Aurelija Pūraitè, Agnè Margevičiūtè. Issues of Financing Lithuanian Higher Education Institutions

higher education in Lithuania: universities and colleges. Universities provide studies of university level, carry out scientific research, focus on experimental research and development of high level professional art. Colleges provide collegiate studies and focus on development of applied sciences and professional art. As of January 2017 - there were 14 state and 9 private institutions of higher education of university level, 16 state and 12 private colleges, 26 science institutes, 18 science institutes within the structure of university (i.e., scientific research and experimental development are implemented, but study programmes are not provided) (Švietimo ir mokslo ministerija [Ministry of Education and Science], 2017). There are three levels of degree granting studies - professional bachelor's and bachelor's, master's, and doctoral.

The system of higher education directly and indirectly involves quite a large number of individuals (up to $70 \%$ of high school graduates). The number of student body population of higher institutions had been consistently increasing from 96 thousand in 2000 to 144 thousand in 2008 (Statistikos departamentas [Department of Statistics], 2010, p. 13). Later, the number decreased to about 133 thousand students in the school year of 2015-2016. There were 93524 students enrolled at universities, and 39772 - in colleges. This represented a 5\% student body population decrease from the school year of 2014-2015. (Statistikos departamentas [Department of Statistics], 2016, p. 10). Of the general population of Lithuania of 30-34 years of age, 56\% had higher education in 2015 (53\% in 2014 ) - an indicator where Lithuania well surpasses the EU aspirations, where it is expected that $40 \%$ of all members of the general population in Member States shall have acquired higher education (or its equivalent) by 2020 (Eurostat, 2015).

The system of financing of higher education of Lithuania has undergone essential changes over the two decades of independence, and the quest for an optimal financing model continues today. The last systematic reform of higher education was completed in 2009. However, it is evident that demographic and economic trends call for yet another attempt at reforming the institutions of science and higher education, a position that is supported by the State Government that commenced its term in 2016. The financing of higher education of Lithuania in comparison with other countries is ordinary and comprises 4-6\% of the GDP (Švietimo ir mokslo ministerija [Ministry of Education and Science], 2010).

The main sources of financing of institutions of higher education in Lithuania are budget allocations, circulating capital (income for providing science, study and other services), target resources (various projects, programmes, financed from the State budget and the EU Structural Funds) and donor resources. State budget allocations are distributed according to the programme principle, based on the number of students eligible for state-financed higher education (as of 2009 - based on the results of admission, i.e., the number of students accepted and the number of 'study purses' received) and results of scientific activity, based 
on the Decision of May $13^{\text {th }}$, 2009, of the Government of the Republic of Lithuania. Initially, budgetary allocations were distributed among the organization of study programmes, scientific research maintenance and administration. However, based on the provisions of Art.67 Sec.2 of the Amendment of April 30 ${ }^{\text {th }}, 2009$, to the Law on Science and Higher Education, budget allocations for institutions of higher education were distributed as a general amount for financing of the costs, i.e., institutions of higher education had the right to decide where and at what extent the allocated monetary resourced were spent.

State budgetary allocations still remain the biggest source of income of the institutions of higher education (See Figure 1). However, their amount in the general structure of income for institutions of higher education is decreasing consistently. Income of higher education institutions from foreign institutions has increased rapidly as of 2004 (almost all of it is the structural support of the EU). However, the system of higher education shall face a substantial shortage of resources in 2020, when the magnitude of the EU support shall decrease, which, in turn, calls for a revision of the financing model of the latter system (Mokslo ir studijų stebėsenos ir analizès centras, [MOSTA], 2016).

\section{Development of financing of the higher education institutions in Lithuania in $1990-2016$}

After the restoration of independence in 1990, the primary model of financing of higher education was bureaucratic both in its regulation and procedures, based on which the financing of institutions of higher education came from the State. The institutional financing method by block - grant funding was applied, where a responsible governmental institution exercised its discretion in determining the set amount of resources to a particular institution of higher education. The main responsibility of financing higher education fell on the State, since resources from the State comprised up to $85 \%$ of all the financial resources received by the institutions of higher education. Resources of the budgets of all institutions of higher education in 1999 were comprised of State budgetary allocations $(75.9 \%)$, resources from international programmes $(5.08 \%)$, student tuition fees (9.98\%), income from other sources (9.04\%) (Antanavičius, A., Guoga, V., Račkauskas, R., et al., 2000, p. 30).

After implementation of the Law on Higher Education in 2000 (Lietuvos Respublikos Aukštojo mokslo įstatymas [Law on Higher Education of the Republic of Lithuania], March 21 ${ }^{\text {st }}, 2000$, No. VIII-1586) and amending the Law on Science and Higher Education (Lietuvos Respublikos Mokslo ir studiju ìstatymo pakeitimo ịstatymas [Law on Amending the Law on Science and Higher Education], June $11^{\text {th }}, 2002$, No. IX-945) the financing of higher education 
changed substantially. It was determined that activities of institutions of science and higher education can be financed from State allocations, resources from the National Fund of Science and Higher Education and other funds, as well as other resources from providing services according to educational programmes, commissions, projects, contracts with national and foreign legal entities, natural persons. The Parliament of the Republic of Lithuania - Seimas - annually determined the amount of block - grant funding allocated to the institutions of higher education: for ordinary expenses (not excluding resources for salaries) and extraordinary expenses as foreseen in the National Programme of Investment in the form of budgetary allocations.

The model of financing of higher education in 2000 fully fit with the features of the collegiate financing model, where an institution of higher education receives state funding according to an agreement between the institution of higher education and the designated governmental institution, based on criteria agreed upon and known in advance. Thus, the state financing of higher education gradually changed from the institutional method to the programme - based funding method, where the main tool of financing involved financing according to the formula, based on various rules and criteria.

A fixed tuition fee was determined for students who finance their higher education studies. Law legitimized the principle of "equality" based on which all students paid the same tuition fee despite the type of the study programme that they were enrolled in. But the size of the tuition fee did not ensure full coverage of higher education studies - allocations from the State budget together with the tuition fees paid by the students covered only about $56 \%$ of all costs related to the studies of higher education (Švietimo ir mokslo ministerija [Ministry of Education and Science], 2007, p. 3).

Ineffective use of financial budgetary resources was also observed by the State Control (Valstybès kontrolè [State Control], 2007), when it determined, after completing an analysis of institutions of higher education in regard to relation between the state budgetary allocations, activity results and quality of education, that budgetary allocations by the State only partially funds education as such, and that universities have to finance the remaining costs of education by redistributing the resources that they would otherwise use for infrastructural purposes, improvement of conditions for science and education, qualification of the employees.

A reform of financing of higher education was implemented in 2009. After long and heated deliberations, the new Law on Science and Higher Education was adopted in April, 2009 (Lietuvos Respublikos mokslo ir studiju ịstatymas [Law on Science and Higher Education], April $30^{\text {th }}, 2009$, No. XI-242) which embedded the following provisions of the system of financing of higher education: i) financial resources of the institutions of higher education are comprised of base 
budgetary allocations by the State; budgetary allocations by the State for education; income derived from tuition fees, as well as income from economic, scientific and other services provided; resources received by way of participation in scientific research programmes; also resources received from State and international funds; resources received from donors and other legitimate sources; ii) State budgetary allocations for each institution of higher education are determined by a separate budget line; iii) base budgetary allocations for state institutions of higher education are designated for scientific research, experimental (social, cultural) development and art; administration and maintenance, other needs; iv) State budget resources are allocated for payment of the tuition cost of the studies financed by the State; to compensate the cost of the studies of the best academically achieved students whose tuition is not financed by the state; scholarships and other purposes; v) number of places of studies financed by the State is determined based on the choice between the institutions of higher education by the best graduates of secondary education programmes, not exceeding the limit of state funding for each sphere of higher education; vi) as of 2012, students are accepted to the target study programme of higher education - study programmes that prepare specialists that the State needs, for example, police officers, public health specialists, etc. A student who has completed a target programme of higher education has an obligation to continue his or her employment in that particular field of occupation for a period of at least three years, and the employer has to finance the education of the future employee; viii) tuition fee is determined by the institution of higher education.

A student loan mechanism started operating in 2009. One of its downsides was that according to the provisions of the Governmental Decision (Lietuvos Vyriausybės $2009 \mathrm{~m}$. gegužès $27 \mathrm{~d}$. nutarimas Nr. 480 [Decision No. 480 of May $27^{\text {th }}, 2009$, of the Government of the Republic of Lithuania]), students who had taken out loans to finance their higher education from commercial banks, had to start repaying the interest of the loan immediately after its reception. Repayment of the loan itself is also carried out in a slightly different manner than it is done in other countries - repayment of the loan commences 12 months after the completion of the programme of higher education (whereas in other countries the term of repayment of the loan is either not determined, is conditioned with reception of income, or is considerably longer).

The Law on Science and Higher Education was amended in June (Lietuvos Respublikos Mokslo ir studiju įstatymo Nr. XI-242 pakeitimo įstatymas. $2016 \mathrm{~m}$. birželio 29 d. Nr. XII-2534 [Law No. XII-2534 of June 29 ${ }^{\text {th }}$, 2016, Amending the Law on Science and Higher Education No. XI-242), which did not bring essential changes in regard to the provisions regulating the system of financing of higher education, but it did alter the notion of resources of education, i.e., the structure of cost of education, by including maintenance costs related to study programmes. 
Saulius Greičius, Birutè Pranevičienè, Aurelija Pūraitè, Agnè Margevičiūtè. Issues of Financing Lithuanian Higher Education Institutions

It is to be noted that the sources of financing of science and higher education after the implementation of the reform did not change substantially - the percentage of state financing within the budgets of some institutions of higher education even increased. Private investment in higher education is barely significant, the financial burden of the State was decreased only on account of EU structural funds and other resourceful programmes. Thus institutions of higher education became even more dependent on State financing.

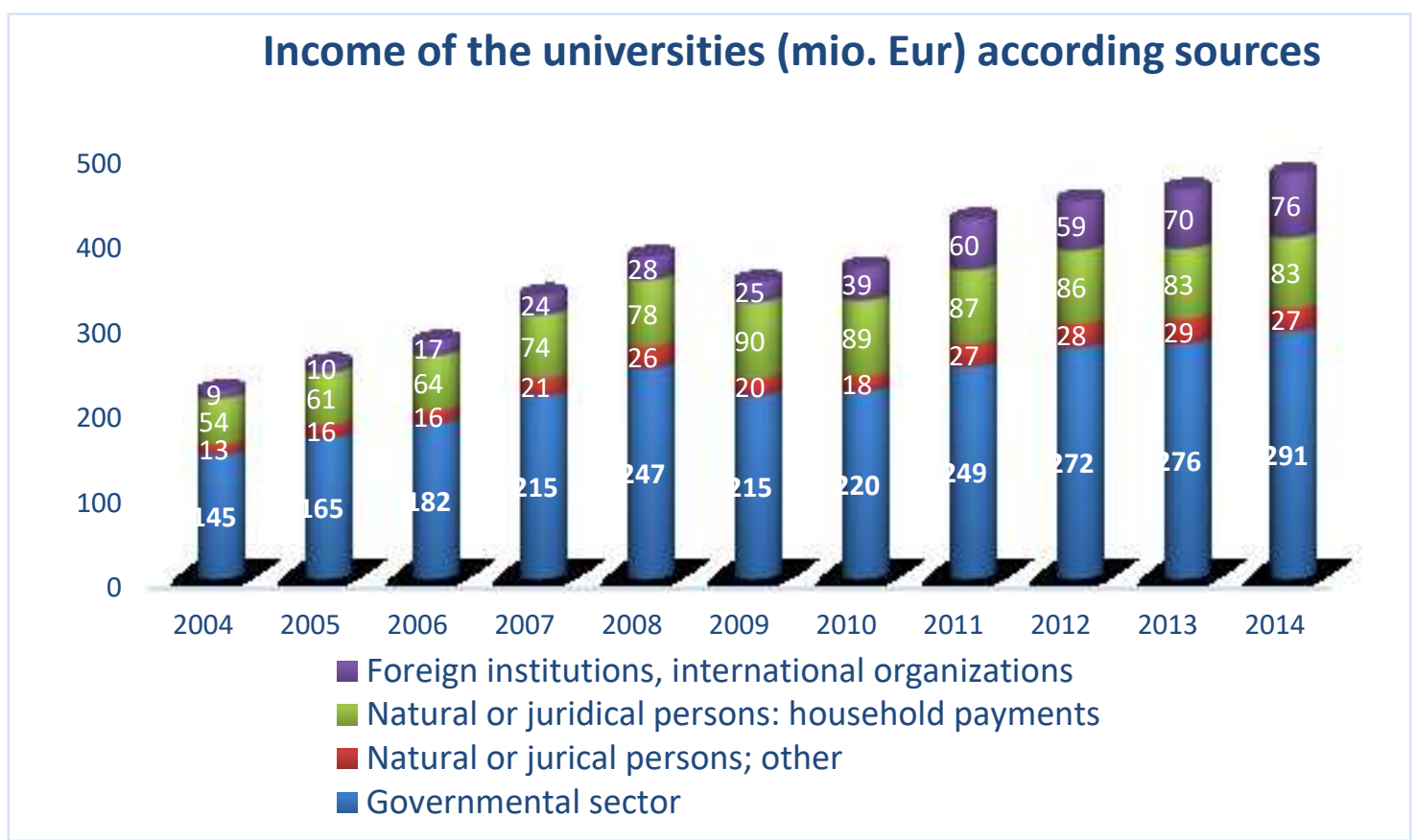

Figure 1 Funds and revenue of universities (mio, Eur) by source

(Statistikos departamentas [Department of Statistics], 2016)

\section{Financing Alternatives of the Institutions of Higher Education in Lithuania}

An analysis of financing (and its alternatives) of higher education calls for discussion on the following aspects: conditions of accessibility of higher education; principles of distribution of State budget allocations to institutions of higher education; principles of determining the number of students for enrolment; system of scholarships; crediting of studies. A long term perspective of any method of financing of higher education should be closely linked with the general increase of quality of higher education, ability to optimize the network of institutions of higher education and create a competitive environment, increasing the amount of financial resources without decreasing the accessibility of higher education, and ensuring the needs on the individual, societal and economic level. 
The price of higher education provided in the "studies' purse" has to fully correspond with the cost of education and cannot be correlated with the demand of the studies formed by students, i.e., have indications of the market price. The price of the first level higher education should not include financing of scientific research of infrastructure. Scientific research (and all related costs) carried out in the interest of the State should be financed from other sources and financing mechanisms (base financing method). The institution of higher education must receive state funding equivalent to the cost of education for each student. Part of the cost of education would be covered from the budgetary allocations, the other part from the registration fee. It is proposed to supplement the financing mechanism of higher education with a new tool of financing - the registration fee that would be determined by the institutions of higher education individually. The registration fee would be payable by all students of the state higher education institutions regardless the form of their studies, or if the studies are financed by the state or not. The registration fee would be payable at the beginning of each semester and would mean that the student is willing to continue his or her studies at that particular programme of higher education during that particular semester. Ability to determine the amount of the registration fee would allow institutions of higher education to plan their revenue individually. Differences between the registration fee would allow competition between the institutions of higher education, but not the programmes. The registration fee could be linked with the number of course credits that the students enrol in, which would also encourage a more thorough selection of the courses, better participation, and higher standards for quality of the education.

Of course, institutions of higher education should continue to accept students who finance their own education. The tuition fee should be left at complete discretion of the institutions of higher education. It is presumed that the registration fee would allow to considerably lower the tuition fee for those students who finance their own education, on the other hand, the tuition fee should remain low due to the competitiveness of the institutions of higher education.

The system of student loans should be revised also. The main focus of revision should be the terms on repayment of the loans that currently determine a defined and rather short loan repayment period (15 years), as well as the declining of the schedule of repayment of the loan. Repayment of the loan that was taken out for financing registration fees and/or tuition fees should be linked only with the income of the graduates of the institutions of higher education. Amounts repaid for the student loans by graduates employed in Lithuania should be made deductible from the income tax in accordance with Article 21 of the Law on Income Tax of Residents (Lietuvos Respublikos gyventojų pajamų mokesčio istatymas [Law on Income Tax of Residents of Republic of Lithuania], July $2^{\text {nd }}$, 2002, No. IX-1007). However, individuals who have received a state provided 
loan or a state guaranteed bank loan should be obligated to file their income in accordance with the legislative provisions. Individuals who have not taken out loans and have financed higher education on their own, and have demonstrated a high level of academic achievement, should be compensated via tax exemptions or directly. Such a method of approval and repayment of student loans is applied in foreign countries such as, for example, Great Britain.

Financial tools that encourage financial support and investment in institutions of higher education by business entities should also be promoted. It is proposed to encourage business and other independent entities to support institutions of higher education directly by, for example, establishing scholarships or paying stipends for current or prospective employees. Therefore, it is necessary to create a necessary legal environment that, for example, allows making deductions from taxed income, profit, based on the amount of financial support that the business entity has allocated to the financing of higher education, etc.

It is evident that the current state of financing of higher education in Lithuania shall face challenges. While the finance model itself is not without flaws, the proposed alternative is neither the only possible nor unquestionable. However, any feasible alternative should be revised, because the demographic crisis and economic challenges in relation to that crisis, decreased EU funding in the future calls for optimization of usage of state resources, otherwise, in light of globalization, the higher education of Lithuania may become diminished and noncompetitive on a global scale.

\section{Conclusions}

The following shortcomings of the system of financing of higher education and its legal regulation are observed: the implementation process of legal regulation is flawed, i.e., even though there are legal norms that regulate certain legal relations, they are not being implemented due to economic reasons (for example, the Government approved methodology on how state funding should be calculated and allocated to specific institutions of higher education, however, due to a difficult financial situation of the state, the funding is not allocated). None of the models or means of financing of higher education ensured sufficient accessibility and quality of higher education and were not efficient in attracting qualified pedagogic personnel. State financial resources still comprise the largest source of income of institutions of higher education, and due to demographic, social and economic reasons the state is unable to provide sufficient financing for institutions of higher education, that, in turn, ensures accessibility and quality of higher education, as well as working conditions compatible with the EU standards for academic personnel of institutions of higher education. 


\section{References}

Albrecht, D., Ziderman, A. Funding Mechanisms for Higher Education. Financing for Stability, Efficiency, and Responsiveness (1992). Washington: World Bank, Downloaded from http://wwwwds.worldbank.org/external/default/main?menuPK=64187510\&pagePK=64 193027\&piPK=64187937\& theSitePK=523679\&menuPK=64154159\&searchMenuPK= 64258545\&theSitePK $=523679 \&$ entityID $=000178830 \_98101903550754 \&$ searchMenuP $\mathrm{K}=64258545 \&$ theSitePK=523679

Antanavičius, A., Guoga, V., Račkauskas, R., et. al. (2000). Lietuvos aukštojo mokslo finansavimas naujajame tūkstantmetyje. Vilnius: EU PHARE programme „Institutional reform of higher education" implementation department.

Aukštojo mokslo reforma. (2007). Studijų finansavimas. Projektinis pasiūlymas. Vilnius: Švietimo ir mokslo ministerija.

Braun, D. (1998). New Managerialism and the Governance of Universities in a Comparative Perspective. In Braun, D., Merrien, F. M. (eds.). Towards a New Model of Governance for Universities.Higher Education Policy Series 53. London and Philadelphia: Jessica Kingsley Publishers.

Canning, M., Godfrey, M., Holzer-Zelazewska, D. Higher Education Financing in the New EU Member States. Leveling the Playing Field. World Bank Working Paper No. 112 (2007) Washington: World Bank. Downloaded from http://www-wds.worldbank.org/ external $/$ default $/$ main?menuPK=64187510\&pagePK=64193027\&piPK=64187937\&the Site $\mathrm{PK}=523679 \&$ menuPK $=64154159$ \&searchMenuPK=64258545\& theSitePK=523679 \&entityID $=000020953 \_20070822083352 \&$ searchMenuPK $=64258545 \&$ theSite $P K=523$ 679

Cazenave, P. Financing of Institutions. Clark, B. R., Neave, G. (eds.) (1992) The Encyclopedia of Higher Education. Oxford, New York, Seul, Tokyo: Pergamon Press.

Claes-Kulik, A. \& Estermann, T. Define Thematic Report: Performance-based Funding of Universities in Europe (2015). Brussels: European University Association. Downloaded from http://www.eua.be/Libraries/publications-homepage-list/define-thematic-report_pbf_final-version.pdf?sfvrsn $=26$

Conraths, B., Smidt, H. (2005). The Funding of University_-Based Research and Innovation in Europe. Brussels: European University Association. Downloaded from http://www.eua.be/publications.aspx\#c400.

Edirisooriya, G. (2003). State Funding of Higher Education:A New Formula. Higher Education Policy, 16.

EUA Report, Financial Sustainable Universities.Towards Full Costing in European Universities (2008). Brussels: European University Association. Downloaded from http://www.eua.be/publications.aspx\#c400

EUA Report, The Funding of University - Based Research and Innovation in Europe (2005) Brussels: European University Association. Downloaded from http://www.eua.be/publications.aspx\#c400

Eurostat regional yearbook 2015 (2015). Luxembourg: Publications Office of the European Union. Downloaded from http://ec.europa.eu/eurostat/documents/3217494/7018888/KSHA-15-001-EN-N.pdf

Glosiene, A. Results and Conclusions of the Monitoring of the EU Structural Funds Use in the Field of Research (2005). Vilnius: Civic Society Institute. 
Saulius Greičius, Birutè Pranevičienè, Aurelija Pūraitè, Agnè Margevičiūtè. Issues of Financing Lithuanian Higher Education Institutions

Johnstone B., Arora A., Experton W. The Financing and Management of Higher Education: A Status Report of Worldwide Reforms (1998). Downloaded from Washington: World Bank http://www-wds.worldbank.org/external/default/WDSContentServer/WDSP/IB/ 2000/07/-19/000094946_99040905052384/Rendered/PDF/multi_page.pdf

Kraujutaitytè, L. Aukštojo moksslo demokratiškumo pagrindai (2002). Vilnius: Lietuvos teisès universitetas.

Kraujutaitytė, L. Finansų politikos modeliai aukštojo mokslo sistemoje. Aukštasis mokslas žiniu visuomenei. Konferencijos pranešimu medžiaga (2003). Kaunas: Technologija.

Lietuvos aukštojo mokslo tendencijos (2016). MOSTA. Downloaded from https://www.smm.lt/uploads/documents/kiti/AM_tendencijos.pdf

Lietuvos Respublikos Aukštojo mokslo įstatymas. 2000 m. kovo 21 d. Nr. VIII-1586. Valstybès žinios, 2000, Nr. 27-715.

Lietuvos Respublikos Gyventojų pajamų mokesčio įstatymas. 2002 m. liepos 2 d. Nr. IX-1007. Valstybès žinios, 2002, Nr. 73-3085.

Lietuvos Respublikos Mokslo ir studijų ịstatymo pakeitimo įstatymas. $2002 \mathrm{~m}$. birželio $11 \mathrm{~d}$. Nr. IX-945. Valstybès žinios, 2002, Nr. 68-2758.

Lietuvos Respublikos Mokslo ir studijų ìstatymas. $2009 \mathrm{~m}$. balandžio $30 \mathrm{~d}$. Nr. XI-242. Valstybès žinios, 2009, Nr. 54-2140.

Lietuvos Respublikos Mokslo ir studijų istatymo Nr. XI-242 pakeitimo i̊statymas. $2016 \mathrm{~m}$. birželio 29 d. Nr. XII-2534. TAR, 2016-07-14, Nr. 20555.

Lietuvos Respublikos Seimo 2012-12-13 nutarimas Nr. XII-51 „Dėl Lietuvos Respublikos Vyriausybès programos“, Valstybès žinios, 2012, Nr. 149-7630.

Lietuvos Respublikos Valstybès kontrolè. Valstybinio audito ataskaita Studiju universitetuose organizavimas ir lèšu, skirtu studijoms ir mokslui bei investicijoms, panaudojimas. 2007 m. gegužès 15 d., Nr. VA-50-4P 920070 Downloaded from www.vkontrole.lt/auditas ataskaita.php?1748

Lietuvos Vyriausybès 2009 m. gegužès 27 d. nutarimas Nr. 480 „Dèl Valstybès paskolų ir valstybės remiamų paskolų studentams suteikimo, administravimo ir grąžinimo tvarkos aprašo patvirtinimo“.Valstybès žinios, 2009, Nr. 64-2569.

Lietuvos Respublikos Vyriausybės 2006 m. spalio 5 d. nutarimas Nr. 974 „Dèl Lietuvos Respublikos Vyriausybès 2004 m. spalio 11 d. nutarimo Nr. 1272 „Dél Lietuvos Respublikos valstybès biudžeto lèšų poreikio nustatymo ir jų skyrimo mokslo ir studijų institucijoms metodikos patvirtinimo" pakeitimo“. Valstybès žinios, 2006, Nr. 108-4114.

Lietuvos Respublikos Vyriausybès 2004 m. spalio 11 d. nutarimas Nr. 1272 „Dèl Lietuvos Respublikos valstybès biudžeto lèšų poreikio nustatymo ir jų skyrimo mokslo ir studijų institucijoms metodikos patvirtinimo“. Valstybès žinios, 2004, Nr. 151-5493;

Lietuvos švietimas skaičiais. 2016. Studijos. (2016). Vilnius: Lietuvos Respublikos Švietimo ir mokslo ministerija.

Lietuvos Švietimas. Tik faktai. Metinis pranešimas (2010). Vilnius: Švietimo ir mokslo ministerija. Downloaded from http://www.smm.lt/svietimo_bukle/docs/-apzvalgos/ Lietuvos\%20svietimas\%202010.pdf.

Pruvot E.B., Claes-Kulik, A., Estermann, T. Designing Strategies For Efficient Funding Of Universities In Europe (2015). Downloaded fromhttp://www.eua.be/Libraries/ publications-homepage-list/designing-strategies-for-efficient-funding-of-universities-ineurope.pdf?sfvrsn=4

Rates of Return and Funding Models ir Europe. Final report to the Directorate-General for Education and Culture of the European Commission. (2007). Valencia: CEGES. 
Salmi J., Hauptman, A.M. Innovations in Tertiary Education Financing: A Comparative Evaluation of Allocation Mechanisms. Education. Working Paper Series. No. 4 (2006) Washington: World Bank Downloaded from http://siteresources.worldbank.org/EDUCATION/Resources/278200-1099079877269/547664109907995681-

5/Innovations_TertiaryEd_Financing.pdf

Salter, B., Tapper, T. The State and Higher Education (1994) Essex: The Woburn Press.

Švietimas. Education. 2015. (2016). Vilnius: Statistikos departamentas.

Švietimas. 2009. (2010). Vilnius: Statistikos departamentas.

Švietimo ir mokslo instituciju kaita pagal teisine forma, grupes ir tipus. Švietimo ir mokslo ministerija. (2017) Downloaded from https://www.aikos.smm.lt/_layouts/15/ Asw.Aikos.Reports/ViewReport.aspx?report $=\% 2 \mathrm{fStatistin} \% \mathrm{C} 4 \% 97 \mathrm{~s}+$ ataskaitos $\% 2 \mathrm{fSM}$ IR+statistin\%C4\%97s+ataskaitos\%2fSMIRInstitucijuKaitaPagalTeisFormaTipus

Wagner, A. Financing Higher Education: New Approaches, New Issues (1996) Higher Education Management, Vol. 8, No. 1.

West, E.G. Education With and Without the State (1995) Washington: World Bank Downloaded from http://www-wds.worldbank.org/external/default/main?menuPK= 64187510\&page $\mathrm{PK}=64193027$ \& $\mathrm{PK}=64187937$ \& theSite $\mathrm{PK}=523679 \&$ menuPK $=6415$ 4159\&searchMenuPK $=64258545 \&$ theSitePK $=523679 \&$ entityID $=000009265 \_3961008$ 065926\&searchMenuPK $=64258545 \&$ theSitePK $=523679$

Woodhall, M. Funding Higher Education: The Contribution of Economic Thinking to Debate and Policy Development. Education. Working Paper Series. No. 8 (2007) Washington: World Bank Downloaded from http://siteresources.worldbank.org/EDUCA-TION/Resources/278200-1099079877269/547664-1099079956815/Funding_Higher Ed_wps8.pdf 